\title{
Book Review: Video games: A waste of time?
}

\author{
Keith McPherson
}

Gee, P. J. (2003). What video games have to teach us about learning and literacy. New York: Palgrave Macmillan. [225 ps. ISBN 1-4039-6169-7].

Recently I joined a dinner party conversation with some colleagues regarding the merits of video games. One person vehemently opposed video games claiming they promoted violence. A second believed that parents should limit video game access at home (although their daughter skirted the problem by playing video games at her friends' house). Another said he couldn't understand their teenager's video game jargon, and wished his child would spend as much time on homework

as they did playing video games. Most people agreed that video games were a "waste of time." I left the conversation wondering "Is there any educational value in children playing video games?"

This is the very question that James Paul Gee, Curriculum and Instruction Professor at the University of Wisconsin, proposes to answer in this publication.

Positioning his exploration of the question in learning and literacy theories on situated cognition (e.g. Bransford, Brown, \& Cocking, 1999), New Literacy Studies (e.g. Barton, 1994; Gee, 1992, 1996), and connectionism (e.g. Clark, 1993), Gee proposes that human literacy is largely shaped by the beliefs, values, cultural models, and meaning-making communication activities particular to the semiotic domains (or discourse groups) to which one ascribes. Gee cites basketball, school, home, and wine connoisseurship (among many) as examples of semiotic domains. The dinner party parent who could not understand his teenager's video game jargon was obviously not privy to the literacy specific to the semiotic domain of video games.

Building on the New London Group's "new literacies" theory (1996), Gee distills thirtysix effective learning principles exhibited by players interacting with 'good' video game software. Primarily, these principles suggest that

- high levels of active engagement are associated with students creating virtual learning identities

- students develop a variety of problem-solving strategies outside of schools' traditional linear thinking models

- students develop capabilities for transferring learned abilities from one semiotic domain to another, and

- virtual experiences help students become adept at connecting with different domains and sign systems, or "multiple literacies." (New London Group, 1996) 
An example of an effective learning principle that develops a variety of student's problem solving strategies is the "Multiple Routes Principle." In this case, Gee claims that video games offer "...multiple ways to make progress or move ahead. This allows learners to make choices, rely on their own strengths and styles of learning and problem solving, while exploring alternative styles" (p. 209).

Gee then compares and contrasts these learning principles with those of schools, concluding, "Games often do a better job at getting themselves learned than schools do in getting things like science learned" (Gee, 2003). He argues that school's failure to ignite a student's love of learning is rooted in the rigid and hegemonic nature of school's learning principles. Principles that 1) closely align themselves to a traditional developmental continuum of literate and social access to power and resources, 2) label the mastery of new texts (including video game 'texts') as 'partial' or 'inferior', and 3) ultimately deny students' full access to the classroom's social and economic power. Any student not conforming to these principles are brought back in line through "skill-anddrill, back-to-basics, test-them-until-they-drop" school curriculum. Unfortunately, these learning principles illustrate schools' limited understanding of the changing role of traditional text and the emergence of new literacies. They also reinforce students' belief that, "Learning is a matter of memorizing information from teachers and books" (p. 162). Gee encourages teachers to critically reflect upon the bias of their own literacy and learning principles, discard video game stereotypes, and seriously consider integrating more powerful learning principles, like those inherent to good video games, into their own instruction.

In a Frierian sounding conclusion (Friere, 1995), Gee urges educators to stop stereotyping games as educationally flawed and video players as "dupes of capitalist marketers." Instead, he encourages educators to join forces with video game producers to create richer and deeper educational experiences "...that lend themselves powerfully to elevating the aspirations and imaginings of all people for better and just worlds" (p. 205).

This text contributes to the larger field of language and literacy education in a variety of ways. First, the arguments encourage further critical discussions and research into the relatively new field of electronic language and literacy learning materials, and the possibility that current video games may be precursors to more powerful future language and literacy learning tools. Second, the thesis effectively folds together three very different theoretical views of literacy and language learning, presenting readers with a credible argument as well as an excellent example of how knowledge and understanding can be built upon new and established language and learning theories in an effort to develop theoretical understandings that keep pace with rapid developments in communication technologies.

Third, the development of new literacy and learning understandings is strengthened by their connections with real world scenarios. For example, Gee proposes that familiarity with the literacy and skills associated with the semiotic domain of video games will assist graduating students to successfully adapt to today's information literacy work places and semiotic domains (e.g., Ebay, electronic banking, Internet marketing, web based 
international retail, etc.). Current research similar to that released by the University of Rochester (Green \& Bavelier, 2003) supports such claims, finding that adolescents who play intense video games exhibit significantly improved cognitive and perceptual skills.

Fourth, Gee's findings support and extend existing literacy research. For example, Smith (1988, p.6) argued that, "[Spoken language] learning is always (1) meaningful, (2) useful, (3) continual and effortless, (4) incidental, (5) collaborative, (6) vicarious, and (7) free of risk." Gee replicates most of these principles, claiming that learning and literacy development in video games is active, critical, encouraging of risk-taking, intuitive, shared with others, and ongoing (p. 207 -212). Unlike Smith, a psycholinguist living in a much different era, Gee draws upon a sociocultural perspective and proposes another thirty principles which, for example, attempt to account for cultural models of language learning, multi modes of literacy, instances when learning is not vicarious, and the importance of skill based learning and instruction.

Fifth, Gee's insights into the collaborative and social nature of networked multiplayer video games lends further credibility to sociocultural theories seeking to explain literacy not just as reading and writing, but as matters of social practice (New London Group, 1996; Street, 1993 \& Lankshear et. al., 1997).

Finally, by focusing on the "educationally sound" learning principles inherent to the semiotic domain of video games, Gee avoids dragging the reader into the fruitless arguments associated with content. Arguments about violence are replaced by discussions about integrating sound learning principles into the classroom.

One shortfall of Gee's thesis lies in the claim that Baby Boomers (thirty five years old) or older will find it difficult to develop a "native-like" literacy in the semiotic domain of video games (p. 5). Such a proposal parallels claims in Gee's (1989) earlier literacy research regarding the difficulty of moving from one's primary or family discourse into a new secondary discourse. Delprit (1993) argued against this claim citing many examples of people (e.g. Malcom X \& Martin Luther King) who maintained their family discourse while learning and using a secondary discourse to acquire social and economic power.

The credibility, reliability and validity of the data supporting Gee's arguments are also suspect. For example, the central thesis, "video games incorporate good principles of learning," is largely supported by observing his own, his daughters, and his university students' video game play. Unfortunately, Gee presents a very sparse discussion on his data collection (e.g. number and types of games played, students observed, and hours spent observing) and sample description (e.g. ages, cultures, gender, socio-economic background). Some literacy researchers and educators may find, as I did, that this lack of verifiable data may render Gee's claims more towards predictive conjecture rather than authentic research.

Similarly, because Gee is drawing upon his on experience as a U.S. citizen, educators from other countries may be reluctant to agree with the generalizability of his findings. For example, unlike many U.S. educators who have recently been grappling with 
curriculum developed around high stake skill-based assessment, most Canadian educators would claim that their curriculum is much less skills based driven, more student-centred and progressive, and thus more closely aligned with Gee's thirty six learning principles.

Gee's arguments also face contradicting evidence from socio-cognitive research studies of preschool children (Olfman, 2003; Healy, 1998). These researchers report that replacing hands-on "play time" with computer programs and games reduced preschool children's creativity, attention spans, learning, and could even lead to social withdrawal, and possibly depression. Healy found "Distracting graphics and special effects, coupled with the temptation to click impulsively, encourage stimulus-bound behaviour which, in turn, contributes to attention problems" (Nuttall-Smith, 2003). These findings question both the educational value of Gee's video game learning principles and their generalizability to very young children.

Although the validity of the data supporting the educational value of video games is questionable, Gee does draw upon credible theory to weave convincing arguments supporting the educational potential of video game learning principles. Arguments which I found challenged the limitations of my own teaching and learning principles, induced me to reevaluate my perspectives on video games, and ponder the possibility that computer games may be a powerful literacy tool of the future. I recommend this book to any language and/or literacy educator wanting to explore the potential of video games as an educational tool.

\section{References}

Barton, D. (1994). Literacy: An introduction to the ecology of written language. Oxford: Blackwell.

Bransford, J. D., Brown, A.L., \& Cocking, R.R. (Eds.). (1999). Rethinking transfer: A simple proposal with multiple implications. Review of research in education 24, 61100 .

Clark, A. (1993). Associative engines: Connectivism, concepts, and representational change. GB: Cambridge University Press.

Delprit, L.D. (1993). The politics of teaching literate discourse. In Perry, T., \& Fraser, J.W. (Eds.), Freedom's plow: Teaching in the multicultural classroom (pp. 285295). New York: Routledge.

Friere, P. (1995). The pedagogy of the oppressed. New York: Continuum.

Gee, J.P. (1992). The social mind: Language, ideology, and social practice. New York: Bergin \& Gavey. 
Gee, J.P. (1989). Literacy, Discourse and Linguistics: Essays by James Paul Gee. Journal of Education 171(1), 5-17.

Gee, J.P. (1996). Social linguistics and literacies: Ideologies in discourses, $2^{\text {nd }}$ ed. London: Taylor and Francis.

Gee, J.P. (2003, August 27). Colloquy Live: Video games in the classroom. The Chronical of Higher Education. Retrieved September 28, 2003, from http://chronicle.com/colloquylive/2003/08/video/

Green, C.S. \& Bavelier, D. (2003). Action video game modifies visual attention. Nature 423, 534-537. http://www.bcs.rochester.edu/people/daphne/GreenandBavelier.pdf

Healy, J.M. (1998). Failure to connect: How computers affect our children's minds - For better or worse. New York: Simon and Schuster.

Lankshear, C.; Gee, J.P.; Knobel, M.; \& Searle, C., (Eds.). (1997). Changing literacies. Buckingham: Open University Press.

New London Group (1996). A pedagogy of multiliteracies: Designing social futures, Havard Educational Review 66(1): 60-92.

Nuttall-Smith, C. (2003, August 9). Computers and pre-schoolers: A trio of new studies says they're a bad mix. The Vancouver Sun, p. A3.

Olfman, S. (2003, August). Too much technology, too little play - The rise of technology and demise of play in preschool education: Pathogenic trends in early childhood education. Paper presented at the meeting of the 111th Annual Convention of the American Psychological Association, Toronto, ON, Canada.

Smith, F. (1988). Joining the literacy club: Further essays into education. Portsmouth, NH: Heinemann.

Street, B. (Ed.) (1993). Cross-Cultural approaches to literacy. GB: Cambridge University Press. 